\title{
Yeni media təhsili və informasiya təhlükəsizliyi
}

\author{
Gülnar Paşayeva \\ AMEA İnformasiya Texnologiyaları İnstitutu, Bakı, Azərbaycan \\ gulnar.amea@gmail.com
}

\begin{abstract}
Xülasə - Yeni medianın vəzifələri və Azərbaycanın media sahəsində informasiya təhlükəsizliyinin təmin olunması məsələlərinə baxılmışdır. İnformasiya təhlükəsizliyinin media sahəsindəki rolu, informasiya müharibəsinin jurnalistikaya, eləcə də cəmiyyətə təsiri məsələləri araşdırılmışdır.
\end{abstract}

Açar sözlor - yeni media, media tohsili, informasiya müharibasi, KIV vo informasiya tohlükosizliyi.

\section{GİRIS}

İnformasiya-kommunikasiya texnologiyalarının (İKT), xüsusən, İnternetin intensiv və sürətli inkişaf,, geniş tətbiqi nəticəsində cəmiyyətin bütün sferalarında köklü dəyişikliklər baş verir, ənənəvi fəaliyyət sahələri transformasiyaya uğrayır, yeni peşə sahələri meydana gəlir [1].

Məlumdur ki, kütləvi informasiya vasitələri (KIV) insan şəxsiyyəti və şüurunun formalaşmasında da güclü psixoloji təsir gücünə malikdir. Çünki ilk növbədə, KİV cəmiyyətdə gedən informasiya prosesinin müxtəlif mərhələləri və tərəflərinə təsir göstərir, rəqəmsal inqilabın meydana çıxmasına səbəb olur.

KİV sahəsində informasiya siyasətinin əhatə etdiyi məsələlərdən biri də milli təhlükəsizliyin tərkib hissəsi olan informasiya təhlükəsizliyinin təmin olunmasıdır. İnformasiya təhlükəsizliyi deyərkən informasiya məkanında ölkənin milli maraqlarının müdafiəssi başa düşülür. Burada medianın da üzərinə böyük missiya düşür [2].

\section{II. İNFORMASIYYA MÜHARİBӘSİ NODİR?}

Kommunikasiya və informasiya sənayesində baş verən ciddi dəyişikliklərdən biri də informasiya müharibəsidir. İnformasiya-psixoloji müharibəsi düşmənə fiziki hücumu nəzərdə tutan müharibə anlayışından fərqlidir. Onun məğzi insanları öz maraqlarının əksinə hərəkət etməyə vadar etməyi, insanları idarə etməyi nəzərdə tutur. Jurnalistlər, media nümayəndələri bu virtual məkanın əsgərinə çevrilirlər - onlar döyüşür, qalib gəlir və "ölürlər” [3].

İlk dəfə "İnformasiya müharibəsi" terminini 1976-c1 ildə amerikalı mütəxəssis Tomas Rona (Thomas Rona) "Boeing" şirkəti üçün hazırladığı "Silah sistemləri və informasiya müharibəsi" adlandırdığı hesabatında istifadə edib. Rona hesabatında sübut etmişdi ki, son illərdə informasiya infrastrukturu ABŞ iqtisadiyyatının əsas komponentinə çevrilib. Bu termin rəsmi olaraq isə ilk dəfə ABŞ Müdafiə Nazirliyi tərəfindən 1992-ci ildə istifadə edilib. Nazirliyin informasiya müharibəsi haqqında sənədlərində bildirilir ki, informasiya həm silah, həm də məqsəddir: informasiya hücumu isə icazə olmadan istənilən formada informasiyanın köçürülməsi, dəyişdirilməsi və məhvinə, habelə proqram təminatlarına, məxfi informasiyanın saxlandığı texniki qurğulara və insan psixologiyasına yönəlmiş əməliyyatdır. ABŞ-da informasiya müharibəsini təsvir etmək üçün çox zaman onu informasiya əməliyyatı ilə müqayisə edirlər. İnformasiya əməliyyatı - məqsədə çatmaq üçün qarşı tərəfin informasiya fəzasına təsir etmək və bu zaman öz informasiya resurslarını qorumaq məqsədi ilə xüsusi metodlardan və vasitələrdən (siyasi, iqtisadi, texniki, hərbi və s.) istifadə etməklə həyata keçirilən mübarizə formasıdır [4].

Bu gün media sahəsində cəmiyyətə təsirin populyar üsulu olan informasiya müharibəsindən geniș istifadə olunur. İntensiv qarşıdurma olan informasiya müharibəsi informasiya məkanında psixoloji və ideoloji üstünlük əldə etmək məqsədilə informasiya sistemləri, proseslər və resurslara, kritiki vacib strukturlara və kütləvi kommunikasiya vasitələrinə zərər yetirilməsini, siyasi və sosial sistemlərin dağıdılmasını nəzərdə tutur [5].

İnformasiya müharibəsinin əsasında məlumatların yayılmasının ən yeni texniki vasitələrindən istifadə dayanır. Radio, televiziya, mobil rabitə və İnternet informasiya müharibəsinin əsas üsullarıdır.

İKT-nin sürətli inkişafı hesabına informasiya müharibəsinin aparılması formaları və metodları da təkmilləşir. Belə ki, ABŞda artıq dezinformasiya stansiyası yaradılmışdır ki, bu qurğu rəqibin radio danışıqlarını əldə etməyə, onların səslərinə yalan məlumatı daxil etməyə və real vaxtda ötürməyə imkan verir [6]. İnformasiya müharibəsinin tərkib hissələrini aşağıdakı kimi qruplaşdırmaq olar:

- psixoloji əməliyyatlar - düşmənin arqumentasiyasına təsir etmək üçün informasiyadan istifadə;

- elektron müharibə - düşmənə dəqiq informasiyanı almağa imkan verməmək;

- dezinformasiya - düşmənə güc və məqsədlər haqqında yalan məlumat vermək;

- fiziki məhv - informasiya sisteminin elementlərinə təsir etmok;

- təhlükəsizlik tədbirləri - düşmənin imkanlar və niyyətlər haqqında məlumat əldə etməsinin qarşısının alınmasi; 


\section{“Informasiya tohlükosizliyinin aktual multidissiplinar elmi-praktiki problemlori” IV respublika konfransı, 14 dekabr 2018-ci il}

- birbaşa informasiya hücumları - qarşı tərəfin yaydığı informasiyanın birbaşa təhrif olunması [7].

\section{YENİ MEDİA TӘHSİLININ VӘZİFӘLӘRİ}

$\mathrm{Bu}$ gün dünyada informasiya qarşılıqlı təsirinin yeni modeli kimi meydana çıxan media vasitələri cəmiyyətin informasiya tələbatını ödəməklə məşğuldur. Buraya televiziya kanalları, informasiya agentlikləri, radio, qəzet və jurnallar, İnternetdə fəaliyyət göstərən xəbər saytları, sosial şəbəkələr, bloqlar və $\mathrm{s}$. aiddir. Bu informasiya axını arasında hansı xəbərin doğru, hansı xəbərin yalnış olduğunu seçmək müasir jurnalistikanın əsas problemlərindəndir. Çünki KİV-in təsiredici funksiyası onun digər, xüsusən də məlumat ötürmə funskiyasını geridə qoymuşdur [8].

Müasir jurnalistika son 10 il ərzində yeni keyfiyyət mərhələsinə qədəm qoymuşdur, bu da informasiyanın maksimum opreativliyinə şərait yaradan yeni texnologiyanın inkişafı ilə bağlıdır. Jurnalistika yeni texnologiya və vasitələrlə zənginləşmiş, yeni anlayışlar, həmçinin yeni jurnalistika alətləri ilə üzləşmişdir [9].

Jurnalistika cəmiyyətdə insanların bir-birilə məlumat paylaşmaq ehtiyacı meydana gəldiyi gündən bəri böyük əhəmiyyət kəsb edir. İnformasiya bolluğu və mürəkkəb ideoloji-psixoloji şəraitdə hədəf auditoriyasını düzgün seçmək, müasir texnologiyalardan istifadə edərək, eləcə də milli-mənəvi dəyərləri nəzərə alaraq xəbər hazırlamaq hər bir jurnalist üçün vacib məqamlardır. Bu mürəkkəb yolda ən mühüm vəzifə media sahəsində fəaliyyət göstərən ali məktəblərin, jurnalistika fakültələrinin, alimlərin və jurnalistlərin üzərinə düşür.

Media təhsili KIV-in (mətbuat, televiziya, radio, kino və s.) qanunauyğunluqlarının öyrənilməsini nəzərdə tutan pedaqoji istiqamətlərdən biri kimi müəyyən edilir. Osas vəzifəsi müasir informasiya şəraitində müxtəlif məlumatların qavranılmasını, informasiyanın psixologiyaya təsirinin nəticələrini təhlil etməyi, texniki vasitələrin köməyi ilə ünsiyyət üsullarına yiyələnməyi öyrətməkdir.

\section{AZӘRBAYCANIN MEDİA SAHӘSINDӘ INFORMASIYYA TӘHLÜKӘSIZLIYI MӘSӘLӘLӘRI}

Qloballaşan dünyada IKKT-nin geniş tətbiqi informasiya təhlükəsizliyi məsələsini ön plana çıxarır. Cəmiyyətin təhlükəsizliyinin əsas elementlərindən biri kimi informasiya təhlükəsizliyinin vəzifələri hər hansı məlumatın konfidensiallığı, tamlığı, əlyetərliyi və kütləvi qorxu (vahimə) yaradan məzmuna qarşı mübarizədir [10].

İternetin imkanları artdıqca, yeni xidmətlərin tətbiqi genişləndikcə, sosial şəbəkələr inkişaf etdikcə, saytların sayı artdıqca insanların siyasi fəallığ 1 da artır. Bütün bunlar informasiya hücumlarının çoxalmasına səbəb olur. Həm də nəzərə almaq lazımdır ki, bu gün ictimai rəyin formalaşdırılması və ya dəyişdirilməsində, bəzi qərarların qəbul edilməsində, qarşı tərəfin informasiya resurslarına təsirində, eləcə də dezinformasiyanın yayılmasında İnternet geniş imkanlara malikdir. Elə bunun nəticəsidir ki, son bir neçə ildə İnternetə informasiya hücumları artmışdır.
Hər bir ölkənin milli təhlükəsizliyinin əsas istiqamətlərindən biri də informasiya təhlükəsizliyidir. Azərbaycan Respublikasının informasiya sahəsində milli təhlükəsizliyinin təmin olunması məqsədi ilə ölkədə informasiyanın, dövlət informasiya ehtiyatlarının müdafiəsi sahəsində milli sistem və informasiya infrastrukturunun inkişaf etdirilməsi və möhkəmləndirilməsi ilə bağlı tədbirlər görülür [11].

Təsadüfi deyildir ki, informasiya təhlükəsizliyinin möhkəmləndirilməsi Azərbaycan Respublikasının milli təhlükəsizlik konsepsiyasında ən mühüm və uzunmüddətli vəzifələrdən biri kimi bəyan edilmişdir: "Azərbaycan Respublikasının informasiya təhlükəsizliyi siyasəti dövlət, ictimai və fərdi informasiya ehtiyatlarının qorunmasına, habelə informasiya sahəsində milli maraqların müdafiəsinə yönəlmiş tədbirlər kompleksinin həyata keçirilməsindən ibarətdir".

Biz bu gün informasiya əsrində, İnternet və digər informasiya texnologiyalarının inkişafı dövründə yaşayırıq. Azərbaycanda siyasi plüralizm hökm sürür, azad mətbuat, İnternet və informasiya orqanları fəaliyyət göstərir, əhalinin böyük bir hissəsi İnternetdən istifadə edir. Lakin qlobal informasiya məkanında İnternetdən, informasiya vasitələrindən, transmilli mətbuatdan bəzən insanların informasiya ehtiyacını ödəməklə yanaşı, həm də xüsusi təxribat vasitəsi kimi istifadə edirlər. $\mathrm{Bu}$ təxribatlar, məqsədyönlü kampaniyalar bəzi hallarda açıq, bəzi hallarda gizli aparılır. Olbəttə, belə şəraitdə ölkələrin informasiya təhlükəsizliyi məsələləri çox aktualdır [12].

Respublikada informasiya təhlükəsizliyinin təmin olunması və informasiya texnologiyalarının inkişafı ilə bağlı milli qanunvericilik bazası xeyli təkmilləşdirilmişdir. "Kütləvi informasiya vasitələri haqqında", "İnformasiya, informasiyalaşdırma və informasiyanın mühafizəsi haqqında", "Məlumat azadlığı haqqında", "İnformasiya əldə etmək haqqında", "Telekommunikasiya haqqında", "Dövlət sirri haqqinda" və s. qanunlarda bu məsələlərə diqqət yetirilmişdir.

Azərbaycan dövlətinin 2013-cü ildə özünün AZӘRSPACE1 video-informasiya ötürücü peykini yeraltı orbitə çıxarması və regionda Rusiya, Türkiyə ilə birlikdə kosmik ölkəyə çevrilməsi onun həm informasiya fəaliyyəti və təhlükəsizliyinin təmin olunmasında mühüm rol oynamış, həm də ölkəyə İKT sahəsində yaxın gələcəkdə böyük uğurlar qazandırmağa şərait yaratmışdır. [13].

\section{MEDİA TӘHSILİ COMIYYӘTIN İNFORMASIYYA TӘHLÜKӘSİLIYIININ TOMIN OLUNMASINDA FAKTOR KIMI}

Müasir cəmiyyətdə informasiya proseslərinin intensivləşməsi sosial mühitin inkişafının obyektiv qanunauyğunluğuna çevrilmişdir: informasiyanın həcmi, ötürülməsi və emalı prosesi sürətlənmişdir. $\mathrm{Bu}$ proseslər insanlara mənfi təsir göstərməklə yanaşı, həm də informasiya yüklənməsinə gətirib çıxarır, bu da öz növbəsində düşünmək və əks etdirmək qabiliyyətini zəiflədir.

Müasir KIV-in gənc nəslin inkişafına təsiri faktı xüsusi narahatlıq doğurur. Comiyyətdə zorakılıq dalğasının geniş 
yayılması, ənənəvi ümumbəşəri dəyərlərin dağıdılması, gənclərdə həssaslığın azalması - bütün bunlar bütovlükdə KİVin müasir vəziyyəti ilə birbaşa bağlıdır.

Dünyada genişmiqyaslı kommunikativ inqilabların baş verməsi cəmiyyətdə informasiya təhlükəsizliyinin təmin olunması problemini daim kəskinləşdirir. 1990-c1 illərin əvvəllərindən etibarən Kanada, Avstraliya və bir sira Avropa ölkələrində ümumi kütləvi informasiya təhsili proqramları fəaliyyət göstərir, media təhsilinə olan tələbat daha da artır. Bu təhsil tələbələrə, gənclərə müasir informasiya məkanında necə davranmaq lazım olduğunu öyrətmək kimi humanist bir funksiyanı yerinə yetirir [14].

XXI əsrdə media təhsili dedikdə, həm də media ilə ünsiyyət mədəniyyətinin formalaşması, kritik düşüncə, yaradıcı və kommunikativ bacarıqların inkişafı, media mətnlərinin təhlili və qiymətləndirilməsi, media texnikalarından istifadə bacarıqlarının öyrədilməsi və s. nəzərdə tutulur.

\section{NӘTİCə}

Müasir KIV nəinki dünya hadisələrini çevik işıqlandırır, həm də informasiyanın təhlili ilə məşğul olur, onu süzgəcdən keçirir və məqsədli şəkildə seçərək istifadə edir, məhz buna görə də insanların şüuruna güclü təsir göstərir. KIV həmçinin tədris, maarifləndirmə, milli-mənəvi və ümumbəşəri dəyərlərin qorunub saxlanılması və inkişaf etdirilməsi funksiyasını yerinə yetirir.

Cəmiyyətin media savadının səviyyəsi informasiya təhlükəsizliyinin təmin edilməsi üçün mühüm əhəmiyyət kəsb edir. Beləliklə, aparılan araşdırmalar aşağıdakı tədbirlərin görülməsini zəruri edir:

- yeni medianın cəmiyyətə təsiri ilə bağlı çoxaspektli tədqiqatların aparılması;

- yeni media sferasında informasiya təhlükəsizliyi problemi ilə bağlı maarifləndirmə işlərinin həyata keçirilməsi;

- ali məktəblərdə informasiya təhlükəsizliyi ilə bağlı yeni ixtisasların yaradılması;

- KIV-də informasiya təhlükəsizliyinin təmin olunmasına yönəlmiş tədbirlərin təşkili.

\section{ӘDӘBIYYAT}

[1] Oliquliyev R.M., Mahmudov R.Ş. İnternet-medianın meydana gəlməsi və inkişafı: əsas istiqamətlər və xüsusiyyətlər, Ekspress-informasiya, İnformasiya cəmiyyəti seriyas1, Bak1, "İnformasiya Texnologiyaları" nəşriyyat1, 2012, $59 \mathrm{~s}$.

[2] www.stj.sam.az - Niyazov.X. "İnformasiya azadlığı və informasiya təhlükəsizliyinin bəzi məsələləri milli təhlükəsizlik kontekstində”, "Strateji təhlil" analitik jurnalı, 2016.

[3] Сергеевич Л. Н. Информационная война как порождение нового времени и современных массмедиа технологий. Часть II. Контуры информационной войны современности http://www.mediascope.ru/1738

[4] www.anl.az/down/meqale/xalqcebhesi/2014/mart/359441.htm

[5] Информационная война, www.mindmeister.com/1022599463

[6] www.mediascope.ru/1738

[7] www.lib.ru/SECURITY/kvn/corner.txt_with-big-pictures.html
[8] Ozyumenko V.I. Media Discourse in an Atmosphere of Information Warfare: From Manipulation to Agression //Russian Journal of Linguistics, 2017, 204 p.

[9] Yeni media, onənəvi media anlayışları, dilanova.wordpress.com/2013/10/27/yeni-media-ənənəvi-mediaanlayislar/

[10] kaspi.az/az/jurnalistika-ve-informasiya-tehlukesizliyi/pages/q.pdf

[11] anl.az/el/Kitab/2016/Azf-291129.pdf

[12] azpress.az/index.php?lang=az\&sectionid=news\&id=24604

[13] azpress.az/index.php?lang=az\&sectionid=news\&id=24604

[14] Коханая.О.Е, Медиаобразование как фактор информационной безопасности общества, «Вестник Московского государственного университета культуры и искусств», 2011, с. 182-187.

\section{NEW MEDIA EDUCATION AND INFORMATION SECURITY}

Gulnar Pashayeva

Institute of Information Technology of ANAS, Baku, Azerbaijan

gulnar.amea@gmail.com

Abstract - This article embraces considerations of new media duties and providing information security in Azerbaijani media. Accordingly, the role of information security in media as well as the effect of information war towards society have been highlighted in the article.

Keywords - new media, media education, information war, media and information security. 